\title{
Hepatic Macrophages are the Cell Source of Hepatic Procalcitonin in Acute Liver Failure
}

\author{
Weiyang Zheng Bingjue Ye Xue Liang Liyan Shui Guohua Lou Yanning Liu \\ Min Zheng
}

The State Key Laboratory for Diagnosis and Treatment of Infectious Diseases, The First Affiliated Hospital, Zhejiang University, Collaborative Innovation Center for Diagnosis and Treatment of Infectious Diseases, Hangzhou, China

\section{Key Words}

Macrophage $\cdot$ Procalcitonin $•$ Lipopolysaccharide $\cdot$ Kupffer cells $•$ Acute liver failure

\begin{abstract}
Background/Aims: Serum procalcitonin (PCT) is elevated in acute liver failure (ALF), but the expression of PCT in the liver has not been elucidated. We aimed to clarify the regulation of hepatic PCT expression and the cell sources in ALF. Methods: Human monocytic leukemia line $U 937$ cells were treated with 12-O-tetradecanoylphorbol-I3-acetate (PMA) (100 ng/ $\mathrm{mL}$ ) for $24 \mathrm{~h}$ to induce activated macrophages. In the presence of lipopolysaccharide (LPS, $1 \mu \mathrm{g} / \mathrm{mL}$ ), activated macrophages and human hepatocyte line L02 cells were incubated with LPS or co-cultured for $0,2,6$, and $24 \mathrm{~h}$. In an in vivo experiment, male C57BL/6 mice were challenged with intraperitoneal LPS/D-galactosamine (LPS/D-GalN). Serum liver enzymes alanine aminotransferase (ALT) and aspartate aminotransferase (AST) were measured using an automatic chemical analyzer. Inflammatory mediators were measured by real-time PCR and liver histology was examined by hematoxylin-eosin (HE) staining and immunohistochemistry (IHC). Results: LPS induced the upregulation of PCT mRNA in U937-activated macrophages but not in L02 cells. When co-cultured with L02 cells, the expression of PCT mRNA of activated macrophages was upregulated compared to controls; however, the activated macrophages did not induce the expression of PCT mRNA in L02 cells in the presence of LPS. Moreover, serum liver enzymes (ALT, AST), inflammation, necrosis, and hepatic expression of PCT were significantly elevated in the LPS/D-GalN-challenged ALF mouse model. IHC revealed that PCT expression was co-localized with hepatic macrophages. Conclusions: Hepatic PCT expression is upregulated in ALF. Hepatic macrophages but not hepatocytes are the cell source of hepatic PCT expression.

W. Zheng and B. Ye contributed equally to this work.

Min Zheng

KARGER
The State Key Laboratory of Infectious Disease Diagnosis and Treatment

The First Affiliated Hospital, Zhejiang University, Hangzhou (China)

Tel. +86-571-87236579, Fax 86-571-87068731, E-Mail minzheng@zju.edu.cn 


\section{Cellular Physiology Cell Physiol Biochem 2018;47:1133-1140 \begin{tabular}{c|c|c|} 
DOI: 10.1159/000490207 & O 2018 The Author(s). Published by S. Karger AG, Basel \\
www.karger.com/cpb
\end{tabular} \\ Zheng et al.: Hepatic Macrophages and PCT Expression in ALF}

\section{Introduction}

Procalcitonin (PCT) is a 116-amino-acid precursor of the hormone calcitonin with a molecular weight of $13 \mathrm{kDa}$ and a half-life in the circulation of 25 to 30 hours [1]. Under physiological conditions, PCT is expressed in the C cells of the thyroid and is not secreted into the circulation. In the 1990s, its association with sepsis was identified and since then PCT has become a diagnostic marker of systemic bacterial infection and is a deciding factor for antibiotic therapy [2]. PCT concentrations are elevated in serum in sepsis and PCT mRNA can be found in multiple tissues throughout the body [3-5]. Some research has shown that the liver expresses high levels of PCT mRNA in septic animals [3, 6]. Moreover, the almost complete loss of the plasma PCT response during severe systemic inflammation in an anhepatic baboon is a reminder that the liver plays an important role in PCT secretion [7]. Acute liver failure (ALF) is a rapidly progressive and severe clinical syndrome that can induce dysfunction and failure in multiple organs [8]. It has been reported that the activation of Kupffer cells in the initial phase is involved in some intense inflammatory responses in the pathogenesis of ALF [9], and serum PCT is elevated in ALF patients [10]. The liver consists of parenchymal cells (hepatocytes) and nonparenchymal cells (Kupffer cells play an important role in inflammation). However, the cells that are control hepatic upregulation of PCT in ALF have not been identified. To clarify whether hepatocytes or hepatic macrophages express PCT in ALF, we used the LPS stimulation model to observe the expression of PCT mRNA in different cell lines and further identify the location of PCT in the liver in a mouse model.

\section{Materials and Methods}

\section{U937 differentiation}

Transwell inserts (Corning, catalog number 353095) were placed into 24-well plates containing 0.6 $\mathrm{mL}$ RPMI/FBS medium per well. U937 (ATCC) cell suspension $\left(0.2 \mathrm{~mL} ; 2 \times 10^{5}\right.$ cells $/ \mathrm{mL}$ ) was added into the inserts $\left(0.4 \times 10^{5}\right.$ cells/insert). Once settled the U937 cells were treated immediately with $100 \mathrm{ng} / \mathrm{mL}$ of PMA (Sigma-Aldrich, catalog number P1585) for $24 \mathrm{~h}$. U937-activated macrophages differentiated in the Transwell inserts after $24 \mathrm{~h}$ in PMA. New 24-well plates were prepared by adding $0.6 \mathrm{~mL}$ of fresh RPMI/FBS media. The PMA-containing medium was then gently aspirated from the inserts.

\section{Co-culture}

L02 cells were obtained from FDCC (Shanghai, China). All cells were cultured at $37^{\circ} \mathrm{C}$ with $5 \% \mathrm{CO} 2$ in DMEM supplemented with $10 \% \mathrm{FBS}, 100 \mathrm{U} / \mathrm{mL}$ penicillin, and $100 \mathrm{U} / \mathrm{mL}$ streptomycin. $\mathrm{L} 02$ cell suspension $\left(1 \mathrm{~mL} ; 2 \times 10^{5} / \mathrm{mL}\right.$ ) was pre-plated into 24 -well plates for $24 \mathrm{~h}$ before co-culture. The inserts with the activated U937 cells were transferred into 24-well plates containing L02 cells.

\section{LPS stimulation}

The inserts and the plates were treated with $1 \mu \mathrm{g} / \mathrm{mL}(10 \mu \mathrm{L}$ of stock solution into $0.8 \mathrm{~mL}$ ) lipopolysaccharide (LPS, Sigma-Aldrich, catalog number: L4391) for 0, 2, 6, and $24 \mathrm{~h}$. U937-activated macrophages and L02 cells were used as reference wells.

\section{Animals and treatments}

Male C57BL/6 mice weighing 21-29 g were purchased from The Experimental Animal Center of Chinese Science Academy (Shanghai, China), and fed a standard laboratory diet and water ad libitum. Experiments were performed after acclimation for 2-3 weeks in a climate-controlled room with a 12-h light-dark cycle and were approved by the Institutional Animal Care and Use committees of Zhejiang University. Mice were challenged with D-galactosamine (D-GalN, $300 \mathrm{mg} / \mathrm{kg}$, Sigma) and LPS (10 $\mu \mathrm{g} / \mathrm{kg}$, Escherichia coli, Sigma) intraperitoneally. Both D-GalN and LPS were diluted in sterile saline (vehicle). Serum ALT and AST levels, as markers of hepatic damage, were measured at baseline and at 2, 6, and $24 \mathrm{~h}$ after LPS/D-GalN injections using an automatic chemical analyzer 7600-100 (Hitachi, Ltd, Tokyo, Japan). Liver tissues were dissected and fixed in 4\% paraformaldehyde and HE via a standard protocol to assess inflammation and necrosis and 


\section{Cellular Physiology Cell Physiol Biochem 2018;47:1133-1140 \begin{tabular}{l|l} 
DOI: 10.1159/000490207 & $\begin{array}{l}\text { O 2018 The Author(s). Published by S. Karger AG, Basel } \\
\text { www.karger.com/cpb }\end{array}$
\end{tabular} \\ Zheng et al:: Hepatic Macrophages and PCT Expression in ALF}

analyzed under a microscope (Nikon ECLIPSE-TE 2000). Paraffin-embedded sections were also stained with polyclonal antibodies for TNF- $\alpha$ (ab6671, Abcam) and PCT (PAA689Mu01, USCN) and visualized using the DAB Substrate Kit for peroxidase (Vector Laboratories). The sections were counter-stained with methyl green solution (Sigma-Aldrich). The numbers of PCT-positive cells per 100 hepatocytes were counted in five different low-power fields.

\section{Real-time PCR}

Total RNA was isolated using Trizol Reagent (Invitrogen, Shanghai, China). The RNA concentration was determined using a NanoDrop Spectrophotometer. cDNA was generated using $0.5 \mu \mathrm{g}$ of total RNA in a final reaction volume of $20 \mu \mathrm{L}$ by PrimeScript ${ }^{\mathrm{TM}}$ RT reagent Kit with gDNA Eraser (Takara, Japan). Quantitative real-time PCR was performed with 7500 Fast Real-Time PCR System (Life Technologies) and SYBR® Premix $\mathrm{Ex}_{\text {Taq }}{ }^{\mathrm{TM}}$ II (Tli RNase H Plus) (Takara). All experiments were conducted according to the manufacturers' protocols. Reactions were started with a polymerase activation step at $95{ }^{\circ} \mathrm{C}$ for $30 \mathrm{~s}$, followed by 40 cycles at $95{ }^{\circ} \mathrm{C}$ for $5 \mathrm{~s}$, and $60{ }^{\circ} \mathrm{C}$ for $30 \mathrm{~s}$. Fluorescence data were acquired after each cycle. The absence of nonspecific products was verified after each run by melting curve analysis. The relative gene quantities were calculated by the $2^{-\triangle \Delta \mathrm{CT}}$ method and compared to the expression levels of GAPDH. GAPDH primers were purchased from Sangon Biotech (B662104-0001, human; B661304-0001, mouse; Shanghai). The sequences of the other primers are listed below:

PCT (human):

forward 5'-TCTAAGCGGTGCGGTAATCT-3';

reverse 5'-TTCTTTCCAGGTGCTCCAAC-3'.

TNF- $\alpha$ (human):

forward 5'-TCTGGGCAGGTCTACTTTGG-3';

reverse 5'-GGTTGAGGGTGTCTGAAGGA-3'.

PCT (mouse):

forward 5' - CAGTGCCTTTGAGGTCAATCT-3';

reverse 5'- CCAGCAGGCGAACTTCTTCTT-3'.

TNF- $\alpha$ (mouse):

forward 5' - CAGGCGGTGCCTATGTCTC-3';

reverse 5'- CGATCACCCCGAAGTTCAGTAG-3'.

\section{Statistics}

Statistical tests were performed using Graphpad Prism software. All statistical differences between the two groups were evaluated using the unpaired two-tailed Student's $t$ test to determine the $P$ values. All data are shown as means \pm standard deviation (SD). Statistical significance was set at $P<0.05$.

\section{Results}

PCT mRNA expression was upregulated in U937-activated macrophages but not in L02 cells in the presence of LPS

PMA incubation for $24 \mathrm{~h}$ induced the activation of U937 cells and differentiation to macrophages. U937-activated macrophages and L02 cells (a normal hepatocyte line) were stimulated by LPS $(1 \mu \mathrm{g} / \mathrm{mL})$ for $0,2,6$, and $24 \mathrm{~h}$. PCT mRNA was up regulated in U937 cells and U937-activated macrophages, and peaked at $6 \mathrm{~h}$; however, PCT mRNA expression was undetected in LPS-stimulated L02 cells (Fig. 1).

Co-culture with U937-activated macrophages or incubation with TNF- $\alpha$ did not induce PCT expression in L02 cells

A co-culture test was performed to further investigate whether the expression of PCT was activated in hepatocytes in inflammatory surroundings. The results showed that coculture with U937-activated macrophages did not induce the expression of PCT in L02 cells, although it was upregulated in co-cultured macrophages. TNF- $\alpha$ which is mainly produced by Kupffer cells in the liver, did not induce PCT expression in L02 cells (Fig. 2). 
Fig. 1. LPS induced upregulation of PCT mRNA in U937 cell line and U937-activated macrophages but not in L02 cells. A: U937 cells were treated with PMA (100 ng/ $\mathrm{mL}$ ) for $24 \mathrm{~h}$ to induce activated macrophages. B: PCT mRNA and TNF- $\alpha$ mRNA were significantly upregulated in U937 cells and U937-activated macrophages but not in L02 cells in the presence of LPS $(1 \mu \mathrm{g} / \mathrm{mL})$. C: qPCR products from (B) were analyzed by agarose gel electrophoresis. * $\mathrm{P}<0.05$; ** $\mathrm{P}<0.01 ; \quad * * * \quad \mathrm{P}<0.001 ; \quad \mathrm{NS}$, not significant; $\mathrm{P}<0.05$, statistically significant.

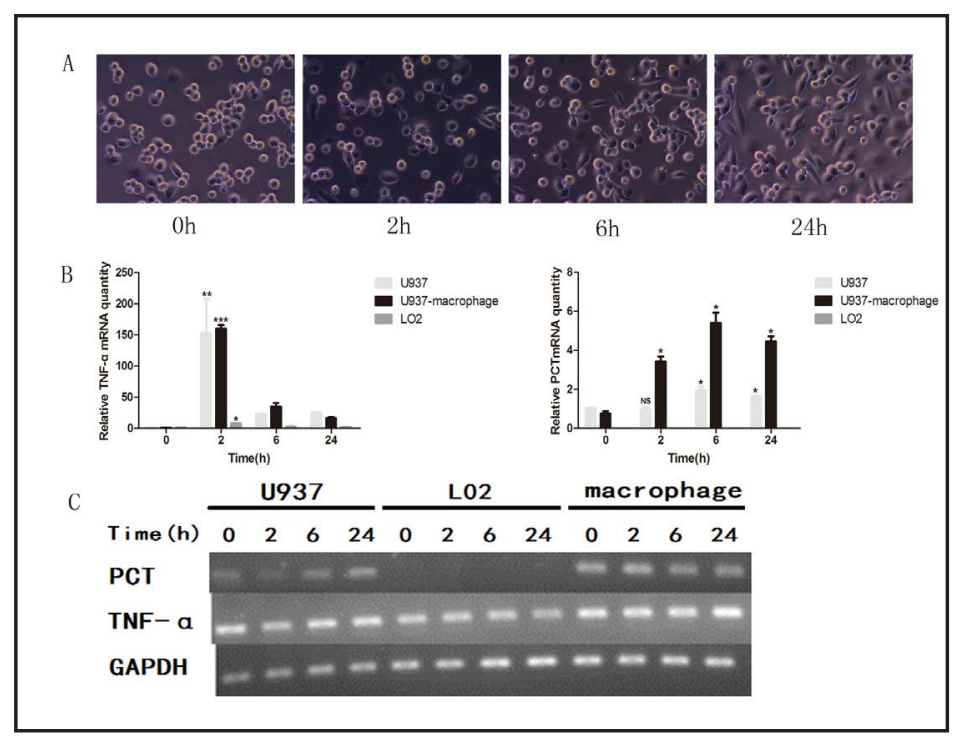

LPS/D-GalN promoted upregulation of hepatic PCT in mice

C57BL/6 mice were challenged by LPS/D-GalN (10 $\mu \mathrm{g} / \mathrm{kg}, 300 \mathrm{mg} / \mathrm{kg}$ ) for $0,1,6$, and $24 \mathrm{~h}$. Serum ALT and AST levels were elevated and peaked at $24 \mathrm{~h}$, at which time obvious liver inflammation and necrosis were present, mainly in the portal area. Importantly, the expression of PCT mRNA was significantly upregulated in the liver, and PCT expression increased in conjunction with liver inflammation infiltration, necrosis, and the expression of TNF- $\alpha$ around the portal area (Fig. 3).

Co-localization of PCT expression and macrophages but not hepatocytes in livers of LPS/D-GalN-challenged mice

PCT is a secreted protein, thus to further identify the location of hepatic PCT expression in mice, C57BL/6 mice were challenged by high doses of LPS/DGalN $(100 \mu \mathrm{g} / \mathrm{kg}, 400 \mathrm{mg} / \mathrm{kg})$ for $1 \mathrm{~h}$. The expression of hepatic PCT mRNA was upregulated and interestingly, hepatic PCT staining radiated through the hepatic lobule and localized in the hepatic sinusoid, which was same pattern as that shown by hepatic macrophages; there was no PCT staining in the hepatocytes (Fig. 4).

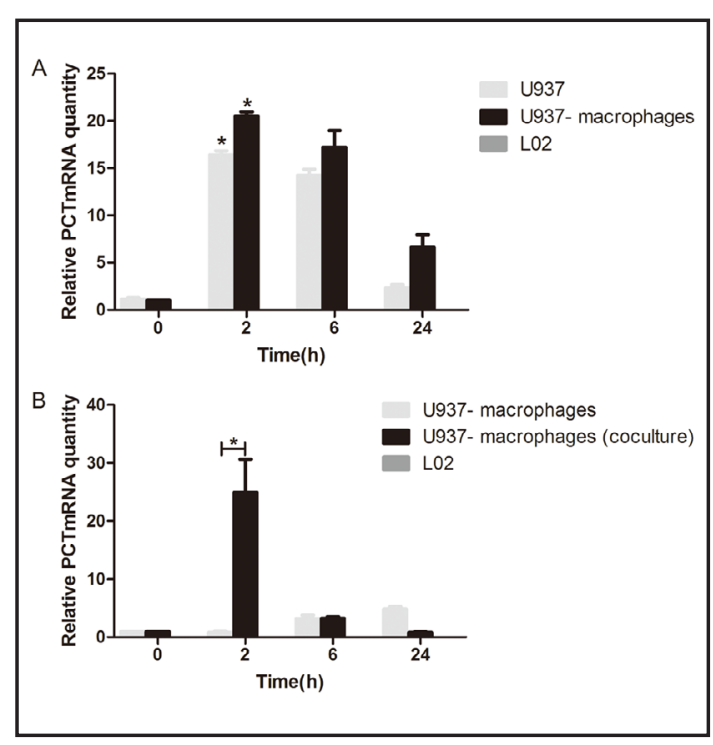

Fig. 2. PCT mRNA expression was absent in L02 cells in inflammatory surroundings formed by LPS-stimulated U937-activated macrophages or TNF- $\alpha$. A: TNF- $\alpha$ (100 ng/mL) induced PCT mRNA upregulation in U937 cells and U937-activated macrophages but not in L02 cells. B: PCT mRNA was significantly upregulated in U937-activated macrophages but not in L02 cells in the co-culture model in the presence of LPS. ${ }^{*} \mathrm{P}<0.05 ; \mathrm{P}<0.05$, statistically significant.

\section{Discussion}

The liver is the largest organ in the human body and is involved in a wide range of functions including detoxification, energy metabolism, hormone production, glycogen 
Fig. 3. Hepatic PCT was significantly upregulated in a LPS/D-GalN-challenged ALF mouse model. A: LPS/D-GalN (10 $\mu \mathrm{g} / \mathrm{kg}, 300 \mathrm{mg} / \mathrm{kg}$ ) induced hepatic inflammation and necrosis in mice, and the expression of hepatic TNF- $\alpha$ and PCT gradually increased with liver inflammation, infiltration, and necrosis around the portal area in the hepatic lobule. B: Upregulation of LPS/DGalN-induced hepatic TNF- $\alpha$ mRNA and PCT mRNA. C: Serum ALT and AST levels were elevated in LPS/ D-GalN-challenged ALF mice. * $\mathrm{P}<0.05$; ** $\mathrm{P}<0.01$; *** $\mathrm{P}<0.001$; NS, not significant; $\mathrm{P}<0.05$, statistically significant.

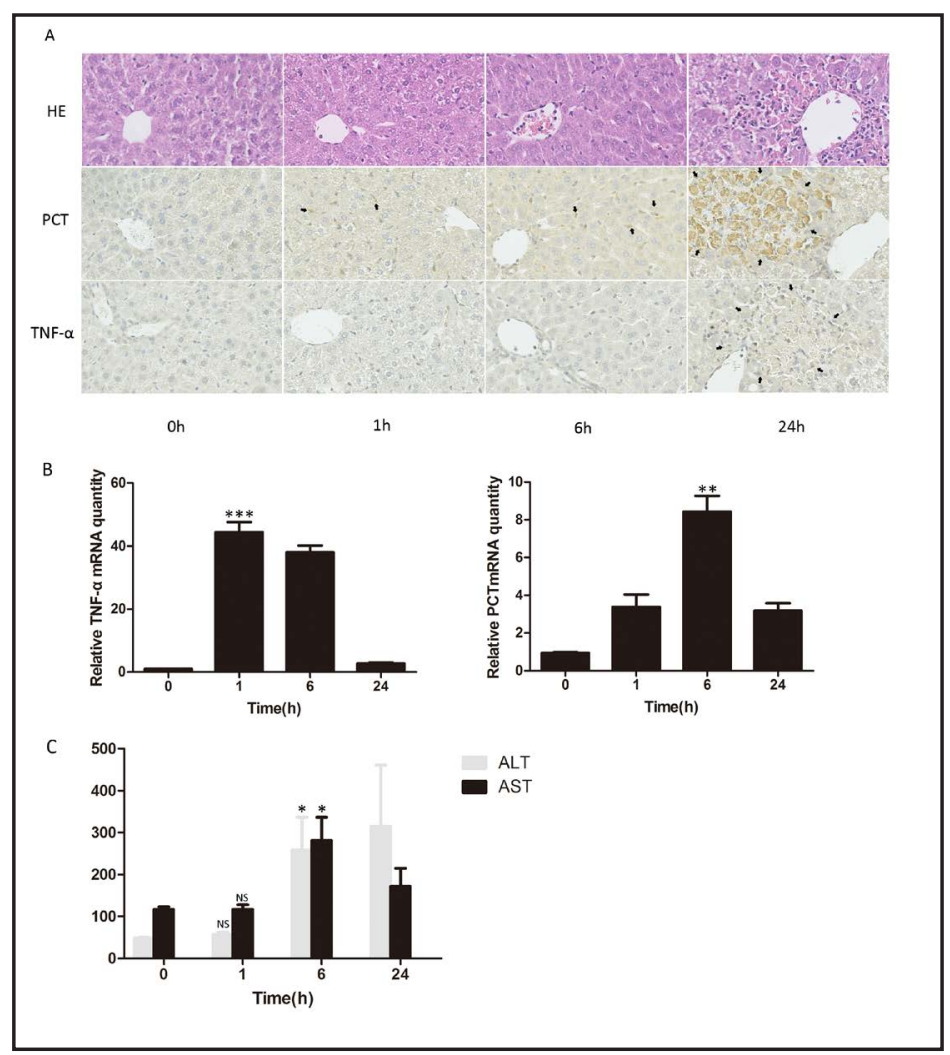

Fig. 4. Hepatic PCT expression was located alongside hepatic macrophages in ALF. A: LPS/DGalN-induced $(100 \mu \mathrm{g} / \mathrm{kg}, 400$ $\mathrm{mg} / \mathrm{kg}$ ) hepatic PCT expression radiated through the hepatic sinusoid and was co-localized with hepatic macrophages but not hepatocytes (IHC). B: The expression of hepatic PCT mRNA and TNF- $\alpha$ mRNA was upregulated in an LPS/D-GalN-challenged ALF mice model. C: Serum ALT and AST levels were elevated in ALF. * $\mathrm{P}<0.05$; ** $\mathrm{P}<0.01$; *** $\mathrm{P}<0.001$; NS, not significant; $\mathrm{P}<0.05$, statistically significant.

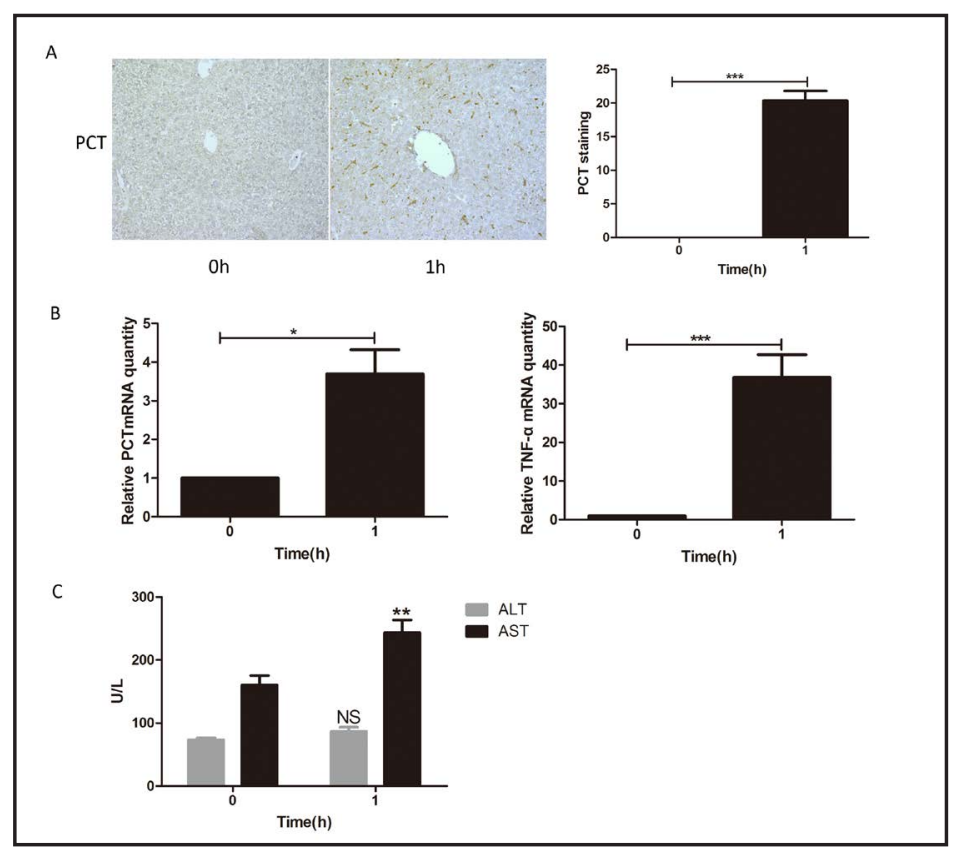

storage, and protein synthesis. Moreover, the liver is also considered a pivotal innate immune organ responsible for the biosynthesis of $80-90 \%$ of acute phase proteins, complement components, and other secreted pattern-recognition receptors of the innate immune system. One of the acute phase proteins, PCT, is a 13-kDa secreted protein found in various organs in sepsis, including the thyroid, liver, lung, small intestine, and kidney [3, $5,7,11]$. It is now known that serum PCT is highly upregulated after surgery and during bacterial infections, and the expression of PCT is induced by LPS and cytokines (TNF- $\alpha$, IL- 
6, IL-1, IL-12). Furthermore, peripheral blood mononuclear cells (PBMCs) express PCT in the presence of LPS or various sepsis-related cytokines both in vitro and in vivo $[12,13]$. Accumulating evidence suggests that serum PCT plays an important role in the diagnosis of bacterial infections $[2,14]$. In contrast to its well-characterized clinical use, neither the mechanisms of PCT expression nor the cell sources have been clarified $[15,16]$. Given that bacterial infection or surgical stress can result in ubiquitous and uniform expression in multiple tissues throughout the body in response to sepsis $[3,17-19]$ and the production of PCT was inhibited in an anhepatic baboon endotoxin shock model [7], it appears that the liver plays a vital role in PCT expression. However, the cell types that are primarily responsible for elevated hepatic PCT levels have not been identified. Thus, we performed experiments using LPS-stimulated cells and a mouse ALF model.

Our results from the in vitro experiments demonstrated that hepatocytes did not express PCT but monocytes and monocyte-activated macrophages upregulated the production of PCT in the presence of LPS or TNF- $\alpha$; this is consistent with previous studies $[13,20]$. Moreover, we performed a co-culture to exclude the possibility of PCT expression being activated in hepatocytes in inflammatory surroundings. Hepatocytes remained quiescent when LPSstimulated macrophages formed inflammatory surroundings; however, interestingly, the expression of PCT was further promoted in macrophages in the co-culture model compared to controls.

We used the LPS/D-GalN-induced ALF mouse model because it is based on the activation of hepatic macrophages and the secretion of cytokines and chemokines, which play an important role in inflammation and necrosis in the liver in the early stages [21,22]. D-GalN sensitizes Kupffer cells to LPS stimulation. It was demonstrated that hepatic PCT mRNA expression was significantly upregulated, and the increase in PCT expression was co-located with liver inflammation, infiltration, and necrosis around the portal area. Although PCT is a secreted protein, we found no PCT staining in hepatocytes following high dose LPS/D-GalNchallenged ALF mice in the early stages $(1 \mathrm{~h})$. The expression of PCT was in the sinusoids in the liver and in a radial arrangement in the hepatic lobule consistent with the location of hepatic macrophages [23]. Hence, it was demonstrated that the expression of hepatic PCT was derived from hepatic macrophages but not hepatocytes.

The mononuclear phagocyte system plays an important role in the immune system $[24,25]$, and macrophages have different names in different organs, for example, Kupffer cells in the liver, Langerhans cells in the lung, microglia in the central nervous system, and osteoclasts in bone [26]. Given that many organs have been shown to produce PCT during sepsis and surgery, it is essential to conduct further studies on the contribution made by the mononuclear phagocyte system and the degree of PCT expression. In our study, hepatic macrophages but not hepatocytes were found to be the cell source of hepatic PCT upregulation in ALF. Moreover, previous studies have shown that serum PCT is elevated in patients with ALF and ACLF [10,27, 28], and the liver is one of the main sources of elevated serum PCT $[7,29,30]$ in sepsis and cytokine storms. Thus, further study is required to clarify the involvement of hepatic PCT-especially that expressed by hepatic macrophages-in the elevation of serum PCT.

\section{Conclusion}

In summary, our study demonstrated that hepatic PCT was upregulated in an LPS/DGalN-challenged ALF mouse model but it was not expressed by hepatocytes. Moreover, LPS and TNF- $\alpha$ induced the expression of PCT in monocytes and activated macrophages but not in hepatocytes in vitro, and PCT was not induced in inflammatory surroundings (cell co-culture model), Therefore, our study suggests that the acute phase protein PCT is upregulated in the liver in ALF and is derived from hepatic macrophages. 


\section{Cellular Physiology Cell Physiol Biochem 2018;47:1133-1140 \begin{tabular}{l|l} 
DOI: 10.1159/000490207 & Ond Biochemistry 2018 The Author(s). Published by S. Karger AG, Basel \\
Published & $\begin{array}{l}\text { www.karger.com/cpb } \\
\text { and }\end{array}$
\end{tabular} \\ Zheng et al.: Hepatic Macrophages and PCT Expression in ALF}

\section{Disclosure statement}

This study was supported by the National Natural Science Foundation of China (No. 81470851) and the major social development projects of Zhejiang S\&T Major Projects of Zhejiang (No. 2015C03045). There are no conflicts of interest to declare.

\section{References}

1 Maruna P, Nedelnikova K, Gurlich R: Physiology and genetics of procalcitonin. Physiol Res 2000;49:S57-61.

$\checkmark 2$ Schuetz P, Müeller B: Procalcitonin in critically ill patients: time to change guidelines and antibiotic use in practice. The Lancet Infectious Diseases 2016;10.1016/s1473-3099(16)00064-5.

-3 Muller B, White JC, Nylen ES, Snider RH, Becker KL, Habener JF: Ubiquitous expression of the calcitonin-i gene in multiple tissues in response to sepsis. J Clin Endocrinol Metab 2001;86:396-404.

4 Zhang F, Fan X, Bai Y, Lu J, Zheng M, Chen J, Liu Y, Chen Z, Zhu J: miR-125b regulates procalcitonin production in monocytes by targeting Stat3. Microbes Infect 2016;18:102-108.

5 Raddant AC, Russo AF: Reactive oxygen species induce procalcitonin expression in trigeminal ganglia glia. Headache 2014;54:472-484.

6 Giunti M, Peli A, Battilani M, Zacchini S, Militerno G, Otto CM: Evaluation of CALC-I gene (CALCA) expression in tissues of dogs with signs of the systemic inflammatory response syndrome. J Vet Emerg Crit Care (San Antonio) 2010;20:523-527.

7 Meisner M, Muller V, Khakpour Z, Toegel E, Redl H: Induction of procalcitonin and proinflammatory cytokines in an anhepatic baboon endotoxin shock model. Shock 2003;19:187-190.

8 Polson J, Lee WM, American Association for the Study of Liver D: AASLD position paper: the management of acute liver failure. Hepatology 2005;41:1179-1197.

-9 Yang F, Lou G, Zhou X, Zheng M, He J, Chen Z: MicroRNA-223 acts as an important regulator to Kupffer cells activation at the early stage of Con A-induced acute liver failure via AIM2 signaling pathway. Cell Physiol Biochem 2014;34:2137-2152.

10 Qu J, Feng P, Luo Y, Lu X: Impact of hepatic function on serum procalcitonin for the diagnosis of bacterial infections in patients with chronic liver disease: A retrospective analysis of 324 cases. Medicine (Baltimore) 2016;95:e4270.

11 Linscheid P, Seboek D, Nylen ES, Langer I, Schlatter M, Becker KL, Keller U, Muller B: In vitro and in vivo calcitonin I gene expression in parenchymal cells: a novel product of human adipose tissue. Endocrinology 2003;144:5578-5584.

12 Oberhoffer M, Stonans I, Russwurm S, Stonane E, Vogelsang H, Junker U, Jager L, Reinhart K: Procalcitonin expression in human peripheral blood mononuclear cells and its modulation by lipopolysaccharides and sepsis-related cytokines in vitro. J Lab Clin Med 1999;134:49-55.

13 Linscheid P, Seboek D, Schaer DJ, Zulewski H, Keller U, Muller B: Expression and secretion of procalcitonin and calcitonin gene-related peptide by adherent monocytes and by macrophage-activated adipocytes. Crit Care Med 2004;32:1715-1721.

14 Taylor R, Jones A, Kelly S, Simpson M, Mabey J: A Review of the Value of Procalcitonin as a Marker of Infection. Cureus 2017;9:e1148.

15 Sbrana A, Torchio M, Comolli G, Antonuzzo A, Danova M, Italian Network for Supportive Care in O: Use of procalcitonin in clinical oncology: a literature review. New Microbiol 2016;39:174-180.

16 Li YM, Liu XY: Molecular mechanisms underlying application of serum procalcitonin and stool miR-637 in prognosis of acute ischemic stroke. Am J Transl Res 2016;8:4242-4249.

17 Franekova J, Secnik P, Jr., Lavrikova P, Kubicek Z, Hoskova L, Kieslichova E, Jabor A: Serial measurement of presepsin, procalcitonin, and C-reactive protein in the early postoperative period and the response to antithymocyte globulin administration after heart transplantation. Clin Transplant 2017;31:1.

18 Perrakis A, Stirkat F, Croner RS, Vassos N, Raptis D, Yedibela S, Hohenberger W, Muller V: Prognostic and diagnostic value of procalcitonin in the post-transplant setting after liver transplantation. Arch Med Sci 2016;12:372-379. 


\section{Cellular Physiology Cell Physiol Biochem 2018;47:1133-1140

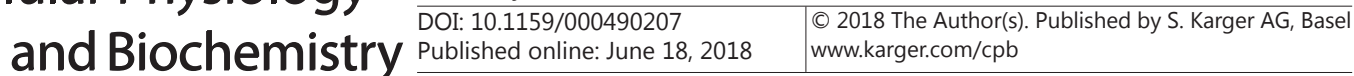 \\ Zheng et al.: Hepatic Macrophages and PCT Expression in ALF}

19 Koerdt S, Rommel N, Rohleder NH, Sandig S, Frohwitter G, Steiner T, Wolff KD, Kesting MR: Perioperative serum levels of procalcitonin, C-reactive protein, and leukocytes in head and neck free flaps. Int J Oral Maxillofac Surg 2017;46:699-705.

-20 Rami D, La Bianca M, Agostinis C, Zauli G, Radillo O, Bulla R: The first trimester gravid serum regulates procalcitonin expression in human macrophages skewing their phenotype in vitro. Mediators Inflamm 2014;2014:248963.

-21 Cardoso FS, Marcelino P, Bagulho L, Karvellas CJ: Acute liver failure: An up-to-date approach. J Crit Care 2017;39:25-30.

-22 Possamai LA, Thursz MR, Wendon JA, Antoniades CG: Modulation of monocyte/macrophage function: a therapeutic strategy in the treatment of acute liver failure. J Hepatol 2014;61:439-445.

23 Marcos R, Correia-Gomes C: Long live the liver: immunohistochemical and stereological study of hepatocytes, liver sinusoidal endothelial cells, Kupffer cells and hepatic stellate cells of male and female rats throughout ageing. Cell Tissue Res 2016;366:639-649.

24 Haniffa M, Bigley V, Collin M: Human mononuclear phagocyte system reunited. Semin Cell Dev Biol 2015;41:59-69.

25 Tang P, Duan C, Wang Z, Wang C, Meng G, Lin K, Yang Q, Yuan Z: NPY and CGRP Inhibitor Influence on ERK Pathway and Macrophage Aggregation during Fracture Healing. Cell Physiol Biochem 2017;41:1457-1467.

26 Ginhoux F, Guilliams M: Tissue-Resident Macrophage Ontogeny and Homeostasis. Immunity 2016;44:439449.

27 Sugihara T, Koda M, Okamoto T, Miyoshi K, Matono T, Oyama K, Hosho K, Okano JI, Isomoto H: Serum Procalcitonin in Patients with Acute Liver Failure. Yonago Acta Med 2017;60:40-46.

-28 Rule JA, Hynan LS, Attar N, Sanders C, Korzun WJ, Lee WM, Acute Liver Failure Study G: Procalcitonin Identifies Cell Injury, Not Bacterial Infection, in Acute Liver Failure. PLoS One 2015;10:e0138566.

-29 Zannoni A, Giunti M, Bernardini C, Gentilini F, Zaniboni A, Bacci ML, Forni M: Procalcitonin gene expression after LPS stimulation in the porcine animal model. Res Vet Sci 2012;93:921-927.

30 Morgenthaler NG, Struck J, Chancerelle Y, Weglohner W, Agay D, Bohuon C, Suarez-Domenech V, Bergmann A, Muller B: Production of procalcitonin (PCT) in non-thyroidal tissue after LPS injection. Horm Metab Res 2003;35:290-295. 